ЩЕБЛИКІНА О. В., асистентка, КАМЕНЄВ О. Ю., к.Т.н., доцент, ЛАПКО А. О., к.Т.н., доцент, САГАЙДАЧНИЙ В. Г., аспіранТ (Український державний університет залізничного транспорту)

\title{
Підвищення показників готовності та відновлення систем керування рухом поїздів на основі збільшення глибини контролю
}

Безперебійність прочесів перевезень залізничним транспортом визначається експлуатаційною надійністю систем керування рухом поӥздів. Одними з найважливіших параметрів, щуо визначають працездатність $і$ справність систем керування, їхню експлуатаційну придатність до регулювання руху поїзів і виконання маневрової роботи, $\epsilon$ готовність та здатність до відновлення. Вони визначаються коефіцієнтами готовності $i$ інтенсивністю відновлення відповідно. 3 метою підвищення цих показників в опублікованому дослідженні, спираючись на останні наукові досягнення, розроблено модель очінювання глибини контролю функиіональних параметрів систем керування рухом поїзів, щңо здійснюються шляхом функиіональних випробувань. На підставі наукових даних, які визначають взаємозв'язок між коефіцієнтом готовності, інтенсивністю відновлення технічних засобів і глибиною їх контролю, встановлено закономірності, щзо визначають збільшення експлуатаиійної готовності та показників відновлення систем керування руху поӥздів при зміні масштабності та складності технологічних об'єктів. Розроблено метод, яких дозволяє на основі збільшення глибини контролю досягти підвищення експлуатаційної готовності та параметра відновлення систем керування рухом поїздів відповідно до 30 \% і до шести разів. 3 урахуванням кореляції між відмовами пристроїв керування рухом поїздів $i$ їх затримками зазначені результати дозволяють зменшити непродуктивний простій поӥздів до $15 \%$.

Ключові слова: системи керування рухом поӥзів, надійність, готовність, відновлення, глибина контролю, тестове покриття, функиіональні випробування.

\begin{abstract}
Вступ
Національною транспортною стратегією України визначено основні напрями розвитку залізничного транспорту до 2030 року. Серед них запровадження комплексних систем цифровізації залізничних перевезень, безперебійність яких безпосередньо залежить від надійності функціонування систем керування рухом поїздів (СКРП). Одними 3 ключових факторів надійності $\epsilon$ експлуатаційна готовність і здатність до відновлення систем керування, актуальність забезпечення яких зростає при впровадженні мікропроцесорних засобів залізничної автоматики.
\end{abstract}

\footnotetext{
Постановка проблеми

Вирішальне значення в забезпеченні експлуатаційної готовності систем керування відіграє реалізація ефективного контролю функціональних параметрів таких систем. Основні ії показники - коефіцієнт готовності та інтенсивність відновлення - безпосередньо випливають із якості виконаного контролю, що пояснюється виявленням та усуненням недоліків систем (відмов, помилок, дефектів) у процесі його виконання. Таким
}

чином, вдосконалення методів, моделей i засобів контролю функціональних параметрів СКРП $є$ дієвим шляхом до підвищення рівня експлуатаційної готовності систем, а отже, забезпечення надійної та безперебійної роботи залізничного транспорту [2-4].

\begin{abstract}
Аналіз останніх досліджень і публікацій
Проблематика контролю функціональних параметрів систем керування відповідальними технологічними процесами охоплена в працях багатьох вітчизняних i закордонних науковців. Зокрема в роботі [5] розглянуто математичні моделі, спрямовані на підвищення швидкостей руху транспортних засобів за рахунок оперативного контролю параметрів надійності відповідних систем регулювання. При цьому відновлення активних модулів керування, що діагностовані в передвідмовному стані, здійснюється на базі ковзного резервування - шляхом за діяння неактивних модулів, що визначаються програмно-апаратними датчиками контролю.
\end{abstract}


У науковій праці [6] опрацьовано питання верифікації параметрів надійності та безпеки функціонування систем автоматизації розподілених об'єктів керування шляхом дослідження їх моделей, побудованих на базі мереж Петрі та ранжирування пріоритетів відновлення. Результати роботи можуть застосовуватися в засобах прогнозування експлуатаційної надійності будь-яких систем, у тому числі мікроелектронних СКРП.

У роботі [7] розглянуто комплексну проблему забезпечення надійності, у тому числі готовності, та убезпечення функціонування СКРП на залізницях СС. Значна увага в роботі приділена методам моделювання технологічних процесів, які дозволяють визначити експлуатаційну готовність СКРП та забезпечити їі на належному рівні 3 використанням неруйнівного контролю функціональних параметрів на базі апарату нечіткої логіки.

У роботі [8] приділено увагу контролю функціональних параметрів СКРП на етапі їх ремонту, при реалізації якого забезпечуються належні показники відновлення та експлуатаційної готовності систем.

Роботи $[9,10]$ спрямовані на вдосконалення підходів до верифікації та валідації мікропроцесорних СКРП на основі тестування програмно-апаратних засобів із використанням імітаційних і комбінованих моделей.

У роботі [11] розроблено методи i моделі контролю функціональних параметрів СКРП на базі графоаналітичного відтворення технологічних об'єктів iз використанням параметрично-топологічних матриць. У праці [12] вдосконалено зазначені методи шляхом використання графо-функціональних моделей i функціонально-топологічних матриць, що дало змогу збільшити глибину контролю функціональних параметрів СКРП.

Проте в усіх зазначених розробках невирішеним залишається питання впливу ефективності контролю функціональних параметрів на показники експлуатаційної готовності для СКРП різного призначення - для об'єктів транспортної інфраструктури з різною масштабністю і складністю.

\footnotetext{
Визначення мети та задачі дослідження

Метою дослідження $\epsilon$ підвищення показників експлуатаційної готовності та параметрів відновлення мікропроцесорних СКРП шляхом збільшення глибини контролю їхніх функціональних параметрів. Для досягнення зазначеної мети вирішуються такі завдання:

- розроблення моделі оцінювання глибини контролю функціональних параметрів СКРП, встановлення іiі обмежень та адекватності;

- розроблення методу синтезу моделей для випробувань СКРП і визначення його ефективності щодо забезпечення належної глибини контролю;
}

- визначення закономірностей, які встановлюють залежності між показниками готовності та відновлення СКРП при збільшенні глибини контролю та зміні параметрів технологічних об' єктів;

- формування рекомендацій щодо застосування розроблених методів, моделей і закономірностей.

\section{Основна частина дослідження}

Модель оцінювання глибини контролю СКРП. Глибина контролю $\epsilon$ основною характеристикою якості функціональних випробувань, що визначає обсяг випробувань відповідно до розмірності (масштабності) об'єкта контролю. Вона характеризується коефіцієнтом глибини контролю як відношення тестового покриття СКРП $N_{\phi m n}$ до іï масштабності $N_{\text {СКРп }}$ :

$$
K_{\text {г }}=\frac{N_{\phi m n}}{N_{\text {СКРП }}} .
$$

Масштабність СКРП є сталою величиною $\left(N_{\text {СКРП }}=\right.$ const), отже оцінка коефіцієнта $K_{\text {гк }}$ визначається параметром тестового покриття $N_{\phi m n}$, що у свою чергу визначається обсягом охоплених випробуваннями множин об'єктів керування та контролю (ОКК) $M_{\text {окк, }}$ програмно-апаратних засобів $M_{n а з}$, функцій СКРП $M_{\phi} \mathrm{i}$ технологічних ситуацій $M_{m c}$. Результуюча множина $M_{m n}{ }^{\mu}$, потужність якої визначає тестове покриття, визначається як бінарне відношення на зазначених множинах [11]:

$$
M_{m n}^{M}=M_{\phi} \times M_{\text {окк }} \times M_{m c} \times M_{\text {паз }},\left[M_{m n}^{M}\right]=N_{\phi m n} .
$$

Відповідно до формули (2) множина $M_{m n}{ }^{\mu}$ формується як перетин модифікованих множин, що $є$ складовими зазначеної формули (рис. 1).

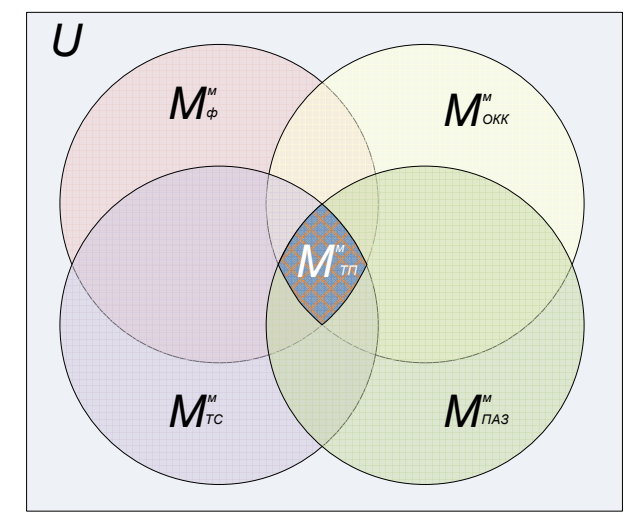

Рис. 1. Діаграма формування множини тестового покриття СКРП 
Зазначена модифікація полягає у формуванні взаємних відношень між взаємопов'язаними складовими тестового покриття:

$$
\begin{aligned}
& \left(M_{\phi}^{M}=M_{\phi} \times\left(M_{\text {окк }} \cup M_{m c} \cup M_{\text {паз }}\right),\right. \\
& M_{\text {окк }}^{M}=M_{\text {окк }} \times\left(M_{\phi} \cup M_{m c} \cup M_{\text {паз }}\right) \text {, } \\
& M_{m c}^{\mu}=M_{m c} \times\left(M_{\phi} \cup M_{\text {окк }} \cup M_{\text {паз }}\right) \text {, } \\
& M_{\text {паз }}^{\mu}=M_{\text {паз }} \times\left(M_{\phi} \cup M_{\text {окк }} \cup M_{m c}\right) \text {, }
\end{aligned}
$$

де $M_{i j}=M_{i} \cup M_{j}-$ об'єднання множин за відношеннями бієктивних зв'язків, між якими відбувається сумування $(i, j=\overline{1,4}) ; i, j=1-$ функції (Ф), 2 - ОКК, 3 - технологічні ситуації (ТС), 4 - ПАЗ.

3 урахуванням встановленої бієкції між складовими тестового покриття, що обумовлена результатами досліджень $[11,13]$, відношення $\prod_{i j} M_{i j}$ у контексті кількості логічних зв`язків між елементами множин $M_{m n}$ визначається чисельною характеристикою, яка прямо або опосередковано визначає кількість зазначених зв`язків. Зазначене співвідношення визначається характеристичними параметрами $x_{j}$, значення яких встановлюються системою лінійних рівнянь

$$
\begin{aligned}
& m_{\phi}=\left[M_{\phi}^{M}\right]=x_{2} \sum_{M_{\phi_{-} \circ \kappa \kappa}} z_{12}+x_{3} \sum_{M_{\phi_{-} m c}} z_{13}+x_{4} \sum_{M_{\phi_{-} \text {паз }}} z_{14}=x_{j} \sum_{M_{1}} \sum_{M_{j}} z_{1 j}, j=\overline{2,3,4},
\end{aligned}
$$

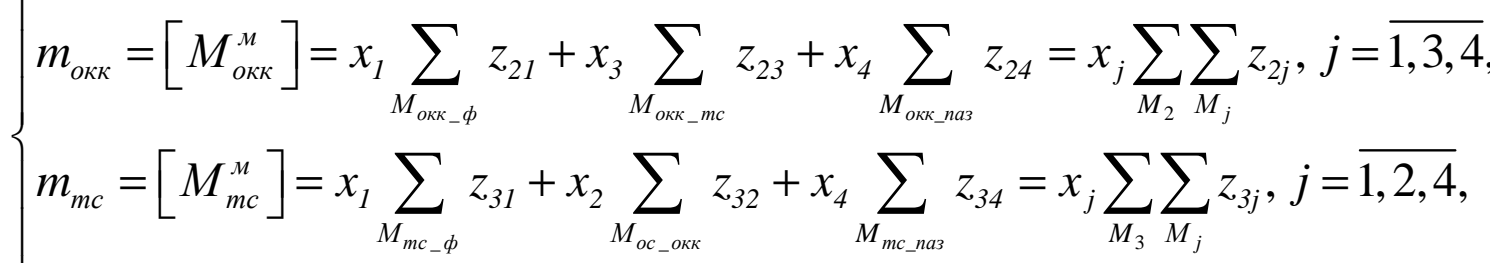

$$
\begin{aligned}
& m_{\text {паз }}=\left[M_{\text {nаз }}^{M}\right]=x_{1} \sum_{M_{\text {nаз_ } \phi}} z_{41}+x_{2} \sum_{M_{\text {nаз_окк }}} z_{42}+x_{3} \sum_{M_{\text {nаз_mc }}} z_{43}=x_{j} \sum_{M_{4}} \sum_{M_{j}} z_{4 j}, j=\overline{1,2,3},
\end{aligned}
$$

де $z_{i j}$ - бієктивні зв'язки між елементами множин $M_{i}$ та урахуванням об'єднання зв'язків $Z_{12} Z_{34}=Y_{1}, Z_{13} Z_{24}=$ $M_{j}$.

Розв'язання системи (4) за правилом Крамера 3

$$
\left\{\begin{array}{l}
x_{1}=\frac{\Delta_{x_{1}}}{\Delta_{Z_{\text {бз }}}}=\frac{2 m_{\phi} Z_{23}+m_{\text {окK }} Z_{34}\left(Y_{1}-Y_{2}-Y_{3}\right)+m_{\text {паз }} Z_{23}\left(Y_{3}-Y_{1}-Y_{2}\right)+m_{m c} Z_{24}\left(Y_{2}-Y_{1}-Y_{3}\right)}{Y_{1}^{2}+Y_{2}^{2}+Y_{3}^{2}-2\left(Y_{1} Y_{2}+Y_{1} Y_{3}+Y_{2} Y_{3}\right)} \\
x_{2}=\frac{m_{\text {окK }} Z_{13} Z_{14} Z_{34}+m_{\phi} Z_{34}\left(Y_{1}+Y_{2}+Y_{3}\right)+m_{\text {паз }} Z_{13}\left(Y_{2}-Y_{1}-Y_{3}\right)+m_{m c} Z_{14}\left(Y_{3}-Y_{1}-Y_{2}\right)}{Y_{1}^{2}+Y_{2}^{2}+Y_{3}^{2}-2\left(Y_{1} Y_{2}+Y_{1} Y_{3}+Y_{2} Y_{3}\right)} \\
x_{3}=\frac{2 m_{m c} Z_{12} Z_{14} Z_{24}+m_{\text {паз }} Z_{12}\left(Y_{1}-Y_{2}-Y_{3}\right)+m_{\text {окK }} Z_{14}\left(Y_{3}-Y_{1}-Y_{2}\right)+m_{\phi} Z_{24}\left(Y_{2}-Y_{1}-Y_{3}\right)}{Y_{1}^{2}+Y_{2}^{2}+Y_{3}^{2}-2\left(Y_{1} Y_{2}+Y_{1} Y_{3}+Y_{2} Y_{3}\right)} \\
x_{4}=\frac{2 m_{\text {паз }} Z_{12} Z_{13} Z_{23}+m_{m c} Z_{12}\left(Y_{1}-Y_{3}-Y_{2}\right)+m_{\text {окK }} Z_{13}\left(Y_{2}-Y_{3}-Y_{1}\right)+m_{\phi} Z_{23}\left(Y_{3}-Y_{1}-Y_{2}\right)}{Y_{1}^{2}+Y_{2}^{2}+Y_{3}^{2}-2\left(Y_{1} Y_{2}+Y_{1} Y_{3}+Y_{2} Y_{3}\right)}
\end{array}\right.
$$

3 метою спрощення виразів (5), що становлять розширену модель оцінювання тестового покриття СКРП, для забезпечення можливості їі прикладного застосування вводяться такі обмеження:

- зв язки $Z_{12,14}, Z_{23,24}, Z_{13,34}$ є взаємно незалежними, що обгрунтовується відокремленістю забезпечення залежностей параметрів $m_{\phi}, m_{\text {окк }}, m_{m c}, m_{\text {паз }} \quad$ за допомогою даних зв язків;

- будь-яка різниця зведених параметрів $Y_{1}, Y_{2}, Y_{3}$ за абсолютною величиною не буде перевищувати детермінант системи (4) 
$\forall i, j, k \in \overline{1,2,3} \Rightarrow\left|Y_{i}-\sum_{j, k} Y_{j, k}\right| \leq\left|Y_{1}^{2}+Y_{2}^{2}+Y_{3}^{2}-2\left(Y_{1} Y_{2}+Y_{1} Y_{3}+Y_{2} Y_{3}\right)\right|$,

що аргументується взаємною бієктивністю всіх попарних зв язків $Z_{12,14}, Z_{23,24}, Z_{13,34}$, звідки випливає рівнозначність потужностей усіх множин $Y_{i, j, k}$;

- у доповнення до попереднього обмеження сума ліворуч від знака «-» у детермінанті системи (5) не буде меншою за відповідну суму праворуч від цього знака, що додатково аргументується першим обмеженням у рамках встановлених умов

$\sum_{i, j, k} Y_{j, k}^{2} \geq \sum_{i, j, k} \prod_{\substack{i, j \\ j, k \\ i, k}} Y_{j, k}$

Зазначені вище обмеження формалізуються розв язанням системи квазілінійних нерівностей, що формується в результаті синтезу виразів (6) і (7) при всіх комбінаціях значень індексів $i, j, k$ для параметрів $Y_{i, j, k}$ :

$$
\left\{\begin{array}{l}
\left|Y_{1}-Y_{2}-Y_{3}\right| \leq\left|Y_{1}^{2}+Y_{2}^{2}+Y_{3}^{2}-2\left(Y_{1} Y_{2}+Y_{1} Y_{3}+Y_{2} Y_{3}\right)\right|, \\
\left|Y_{2}-Y_{1}-Y_{3}\right| \leq\left|Y_{1}^{2}+Y_{2}^{2}+Y_{3}^{2}-2\left(Y_{1} Y_{2}+Y_{1} Y_{3}+Y_{2} Y_{3}\right)\right|, \\
\left|Y_{3}-Y_{1}-Y_{2}\right| \leq\left|Y_{1}^{2}+Y_{2}^{2}+Y_{3}^{2}-2\left(Y_{1} Y_{2}+Y_{1} Y_{3}+Y_{2} Y_{3}\right)\right|, \\
Y_{1}^{2}+Y_{2}^{2}+Y_{3}^{2} \geq 2\left(Y_{1} Y_{2}+Y_{1} Y_{3}+Y_{2} Y_{3}\right) .
\end{array}\right.
$$

Усунення операції взяття абсолютної величини в системі (8) буде виправданим в умовах додаткового обмеження, що полягає в перевищенні суми будь-яких значень $Y_{j, k}$ над будь-яким значенням $Y_{i}\left(Y_{j}+Y_{k}>Y_{i}\right)$, що обгрунтовується чисельністю і бієктивністю зв язків:

$\begin{gathered}\forall Y_{i, j, k}>0 \\ Y_{i}<\sum_{j, k} Y_{j, k}\end{gathered} \Rightarrow\left|Y_{i}-\sum_{j, k} Y_{j, k}\right| \Rightarrow \sum_{j, k} Y_{j, k}-Y_{i}=\sum_{-i,+j,+k} Y_{i, j, k}$

3 урахуванням додатного значення кількості зв язків $Y_{i, j, k}$ синтез виразів (8) і (9) призводить до модифікованої системи нерівностей

$$
\begin{gathered}
{\left[Y_{i, j, k}\right]^{2}>\left[Y_{i, j, k}\right]} \\
{\left[Y_{i, j, k}\right] \in Z} \\
\sum_{j, k} Y_{j, k}-Y_{i} \leq \sum_{i, j, k} Y_{j, k}^{2}-\sum_{\substack { i, j, k \\
\begin{subarray}{c}{i, k \\
j, k \\
i, k{ i , j , k \\
\begin{subarray} { c } { i , k \\
j , k \\
i , k } }\end{subarray}} \prod_{\substack{i, j \\
j, k \\
i, k}} Y_{j, k},
\end{gathered}
$$

розв язання якої на кількісному полі множин зв'язків СКРП визначається поверхнями, зображеними на рис. 2.

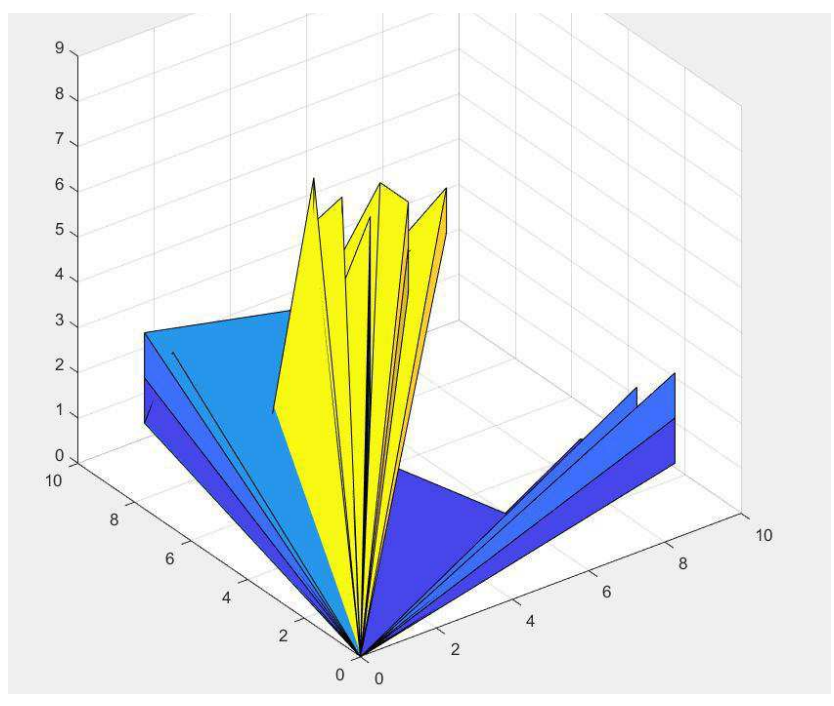

Рис. 2. Графічні області обмежень моделі тестового покриття функціональних випробувань СКРП

3 урахуванням встановлених обмежень розв'язання системи (10) визначає таку модифіковану модель оцінювання тестового покриття: 
$\frac{1}{Y_{1}^{2}+Y_{2}^{2}+Y_{3}^{2}-2\left(Y_{1} Y_{2}+Y_{1} Y_{3}+Y_{2} Y_{3}\right)} \rightarrow \max$

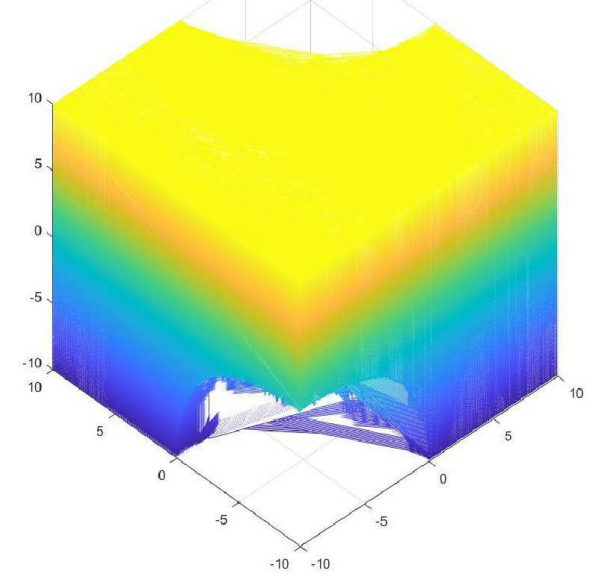

Область ii суперпозицією поверхонь, зображених на рис. 2, 3 поверхнями, що відображують систему (5), наведеними на рис. 3.

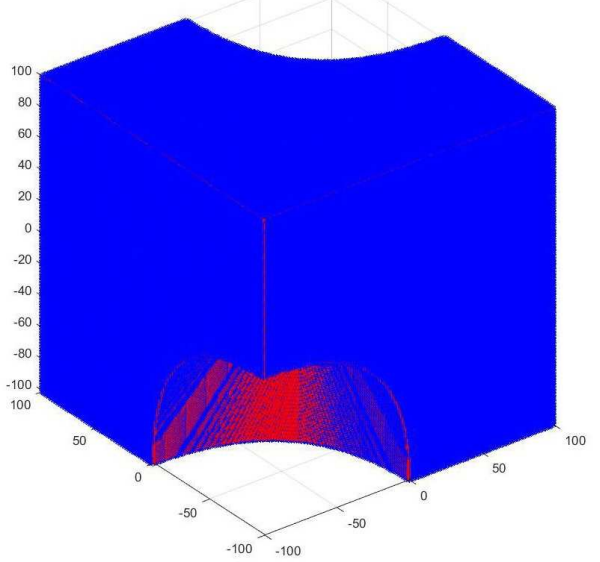

Рис. 3. Поверхні, які інтерпретують еталонні вирази для оцінювання адекватності моделі оцінювання тестового покриття

На підставі встановлених значень похибок моделі оцінювання тестового покриття визначаються можливі діапазони використання моделей для випробувань СКРП 3 урахуванням потужності зв'язків між відповідними складовими.

Метод синтезу моделей для випробувань СКРП. На підставі графо-функціональних методів відтворення технологічних об'єктів СКРП, запропонованих у роботі [12], модель для випробувань таких систем керування базується на аналітичному поданні ОКК, їхніх зв'язків і властивостей на базі функціонально-топологічних матриць суміжності (СФТМ), змістовне наповнення яких відбувається за діагональним принципом (рис. 4).

При такому підході в основу СФТМ покладаються iii діагональні блоки ФТМ, що розмежовуються матрицями

$$
G_{\partial}^{l / l+1}\left(v_{i}, v_{j}, e_{i j}\right) \leftrightarrow\left|M_{\partial}^{l / l+1}\right|=\left|\begin{array}{cc}
f_{i}\left(\overline{u_{i}}\right) & 1 \\
1 & f_{i+1}\left(\overline{u_{i+1}}\right)
\end{array}\right|,
$$

які інтерпретують опорні елементарні дерева $G_{\partial}^{l / l+1}$ між суміжними компонентами $l$ i $l+1$ графофункціональної моделі СКРП $G_{Y F}$.

У таких умовах модель для випробувань СКРП, яка відтворює іiї технологічний об єкт, визначається повною діагональною СФТМ у вигляді

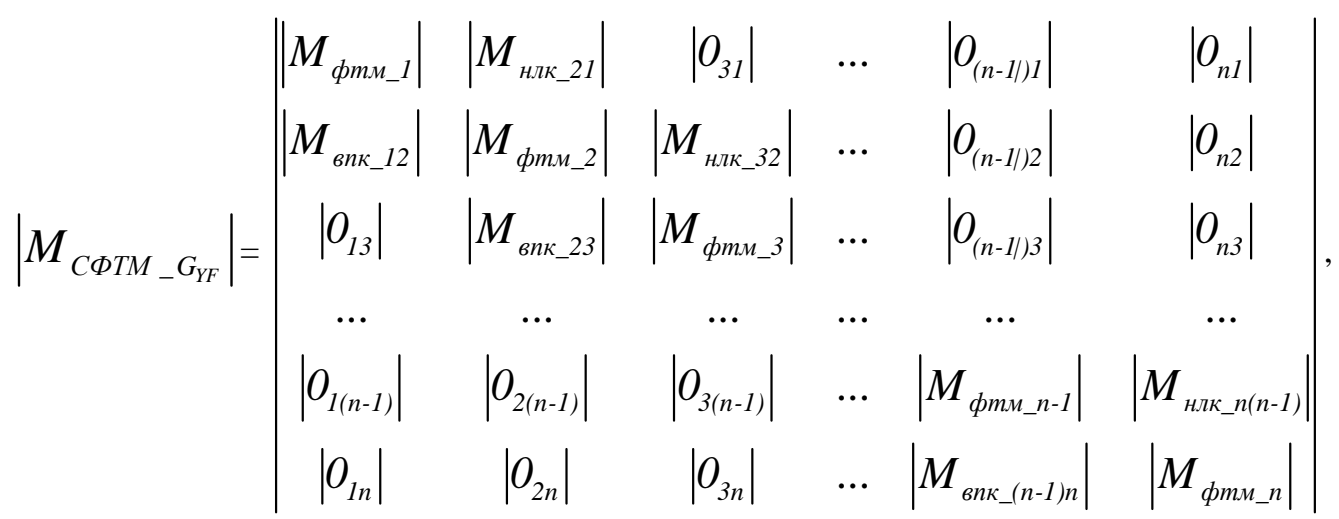


де блоки ФТМ $\left|M_{\phi m n_{-} l}\right|$, сусідні з ними додаткові матриці $\left|M_{\text {впк_l(l+1) }}\right|,\left|M_{\text {нлк_(l+1)l }}\right|$ і нуль-матриці розмежованими опорними елементарними деревами (12).

За таких умов СФТМ (13) визначається $\left|0_{(l \pm i)(l \mathrm{mj})}\right|$ визначаються за компонентами графа, поєднанням прямих сум

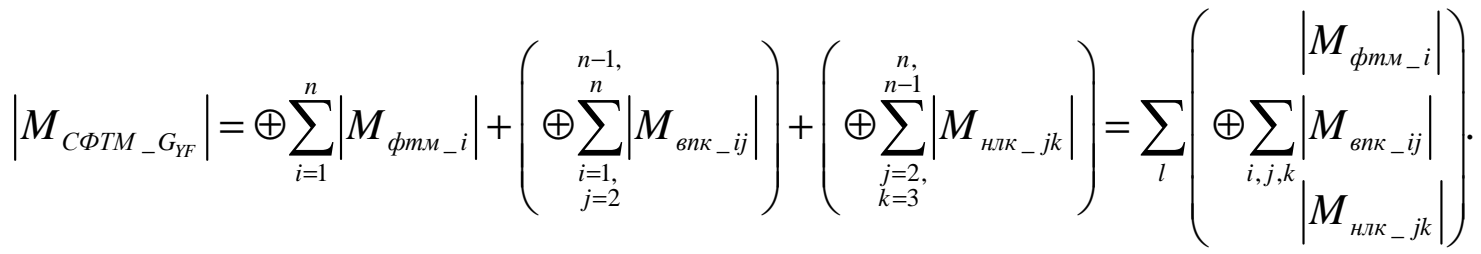

Зображений виразом (14) метод синтезу моделей для випробувань отримує назву методу модифікованих прямих сум (ММПС). На відміну від методу прямих сум (МПС), запропонованого в працях [11, 14], ММПС відтворює динамічні характеристики ОКК за рахунок використання їхніх функціоналів $f_{i}\left(\overline{u_{i}}\right)$ і базується на використанні матриць суміжності, а не інцидентності.

\begin{tabular}{|c|c|c|c|c|c|c|c|c|}
\hline & $V_{1}$ & $V_{2}$ & --- & $\mathbf{V}_{\mathbf{i}}$ & $V_{i+1}$ & $V_{i+2}$ & $V_{i+---}$ & $V_{\text {i+--- }}$ \\
\hline $\mathbf{V}_{1}$ & $f_{1}\left(u_{1}\right)$ & $\Theta_{12}$ & --- & $\theta_{1}$ & C & $\mathrm{C}$ & C & C \\
\hline$V_{2}$ & $\Theta_{21}$ & $\mathrm{f}_{\bar{z}}\left(\mathrm{U}_{\bar{z}}\right)$ & --- & $\Theta_{2}$ & C & C & $\mathrm{C}$ & $\mathrm{C}$ \\
\hline --- & --- & --- & f_-(u__. & --- & --- & --- & --- & --- \\
\hline $\mathbf{V}_{\mathbf{i}}$ & $\theta_{1}$ & $\theta_{2}$ & --- & $f(u)$ & 1 & C & C & $\begin{array}{l}1 \\
1 \\
1\end{array}$ \\
\hline$V_{i+1}$ & C & C & C & 1 & $f_{+1}\left(u_{+1}\right)$ & $\theta_{+1(+2)}$ & $\theta_{+1(+--)}$ & $\Theta_{+1(+-\infty)}$ \\
\hline$V_{i+2}$ & C & C & C & C & $\theta_{+2(+1)}$ & $f_{+2}(U+z)$ & $\theta_{+2(+-)}$ & $\Theta_{+2(+-)} 1$ \\
\hline $\mathbf{V}_{\mathbf{i + -}--}$ & C & C & C & C & $\Theta_{+-(+1)}$ & $\Theta_{+\ldots}$ & $f_{+-}\left(u_{+--}\right)$ & $\theta_{++-(+-)}$ \\
\hline$V_{i+---}$ & $\mathrm{C}$ & C & C & C & $\theta_{+--(+1)}$ & $\theta_{+--(+2)}$ & $\theta_{+--(+--)}$ & $f_{+\ldots}\left(U_{+\ldots}\right)$ \\
\hline
\end{tabular}

Рис. 4. Структура змістовного наповнення СФТМ

Оцінка ефективності ММПС порівняно зі своїм найближчим аналогом МПС за критерієм збільшення глибини контролю (тестового покриття) випробувань базується на встановленому зв'язку потужності множин тестового покриття 3 моделлю його оцінювання, який відповідно до виразів (2) - (4), (11) визначається як 


$$
\begin{aligned}
& \left\{\begin{array} { l } 
{ [ B = \{ b _ { i } \} ] \nearrow } \\
{ [ C = \{ c _ { j } \} ] \nearrow } \\
{ [ D = \{ d _ { k } \} ] \nearrow } \\
{ [ L ] = \{ l _ { l } \} \nearrow }
\end{array} \Rightarrow \left\{\begin{array} { l } 
{ [ M _ { \phi } ^ { M } ] \nearrow } \\
{ [ M _ { o k \pi } ^ { M } ] \nearrow } \\
{ [ M _ { m c } ^ { M } ] \nearrow } \\
{ [ M _ { n a s } ^ { M } ] \nearrow }
\end{array} \Rightarrow \left\{\begin{array}{c}
\left(Y_{1} Y_{2}+Y_{1} Y_{3}+Y_{2} Y_{3}\right) \nearrow \\
\left(Y_{1}^{2}+Y_{2}^{2}+Y_{3}^{2}\right) \swarrow
\end{array} \Rightarrow\right.\right.\right. \\
& \Rightarrow\left(\frac{1}{Y_{1}^{2}+Y_{2}^{2}+Y_{3}^{2}-2\left(Y_{1} Y_{2}+Y_{1} Y_{3}+Y_{2} Y_{3}\right)}\right) \nearrow \Leftrightarrow \\
& \Leftrightarrow \frac{1}{Y_{1}^{2}+Y_{2}^{2}+Y_{3}^{2}-2\left(Y_{1} Y_{2}+Y_{1} Y_{3}+Y_{2} Y_{3}\right)} \rightarrow \max ,
\end{aligned}
$$

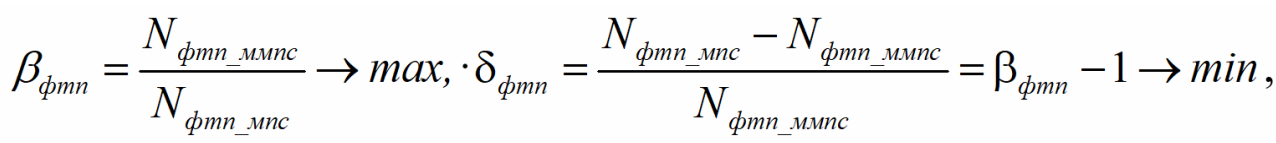

які визначають відповідні співвідношення між параметрами $N_{\text {фтп }}$ для ММПС та МПС.

Шляхом поєднання виразів (15) і (16) визначається

вираз для критерію ефективності з урахуванням моделі оцінювання тестового покриття

де $\mathrm{B}, \mathrm{C}, \mathrm{D}$ i L - відповідно впорядковані множини (вектори) вагових параметрів ОКК, що інтерпретуються графічною моделлю СКРП і відповідають зазначеним множинам тестового покриття.

Ефективність методу оцінюється за критеріями

$$
\begin{aligned}
& \beta_{\text {中тा }} \sim \frac{\left(Y_{2}-Y_{3}\right)^{-2}}{\left[Y_{1}^{2}+Y_{2}^{2}+Y_{3}^{2}-2\left(Y_{1} Y_{2}+Y_{1} Y_{3}+Y_{2} Y_{3}\right)\right]^{-1}}=\frac{\left(Y_{2}-Y_{3}\right)^{2}+Y_{1}^{2}-2\left(Y_{1} Y_{2}+Y_{1} Y_{3}\right)}{\left(Y_{2}-Y_{3}\right)^{2}}= \\
& =1+\frac{Y_{1}^{2}-2\left(Y_{1} Y_{2}+Y_{1} Y_{3}\right)}{\left(Y_{2}-Y_{3}\right)^{2}}=1+\frac{Y_{1}^{2}-2 Y_{1} Y_{2}-2 Y_{1} Y_{3}+Y_{2}^{2}-Y_{2}^{2}}{\left(Y_{2}-Y_{3}\right)^{2}}=1+\frac{\left(Y_{1}-Y_{2}\right)^{2}-2 Y_{1} Y_{3}+Y_{2}^{2}}{\left(Y_{2}-Y_{3}\right)^{2}} .
\end{aligned}
$$

Виходячи зі встановленої у роботі [11] взаємнооднозначної відповідності між ОКК та його функціями $\left(a_{i} \leftrightarrow f_{i}\left(u_{i}\right)\right)$, а також характер зв'язків між компонентами тестового покриття, значення $Y_{1}$ можна вважати приблизно рівним значенню $Y_{2}$ у межах кожного технологічного об' єкта СКРП ( $\left.Y_{1} \approx Y_{2}\right)$. Таким чином, відповідний критерій ефективності визначається як

$\beta_{\text {фтा }} \sim 1+\frac{\left(Y_{2}-Y_{2}\right)^{2}-2 Y_{2} Y_{3}+Y_{2}^{2}}{\left(Y_{2}-Y_{3}\right)^{2}}=1+\frac{Y_{2}\left(Y_{2}-2 Y_{3}\right)}{\left(Y_{2}-Y_{3}\right)^{2}}$.

Відповідно до виразу (17) на рис. 5 побудовано графічні 3D-залежності, які визначають характер

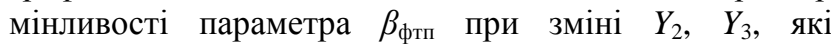
визначають відповідно складність і масштабність СКРП.

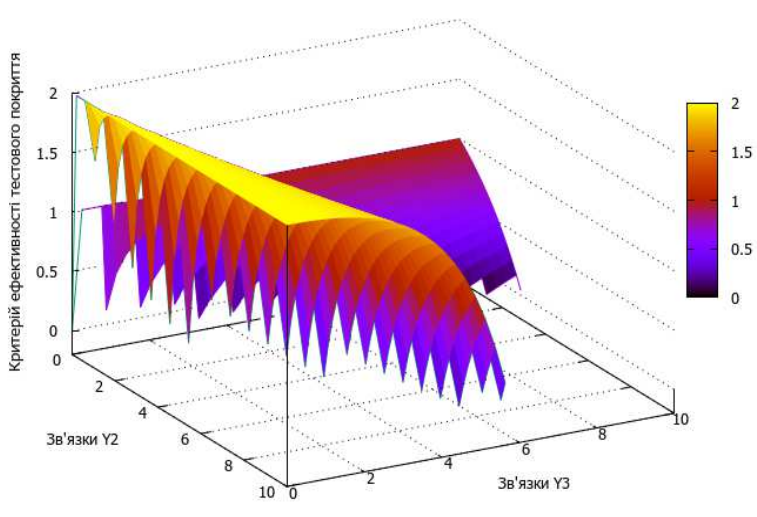

$1+\left(x^{*}\left(x-2^{*} y\right) /((x-y) *(x-y))\right)$

Рис. 5. 3D-графік орієнтованої (пропорційної) оцінки критерію ефективності тестового покриття $\beta_{\text {фтп }}$

3 наведеного графіка вбачається, що до точки нескінченного розриву $Y_{2} \approx Y_{3}$ при збільшенні кожного 3 цих параметрів відбувається зменшення значень $\beta_{\text {фпп, }}$, що цілком відповідає критерію ефективності ММПС, 
встановленого виразом (16). Фактично це означає, що розроблений метод буде мати різну ефективність порівняно 3 найближчим аналогом при різних значеннях складності і масштабності СКРП з різними тенденціями монотонності при відповідних співвідношеннях.

Оцінювання експлуатаційної готовності СКРП. Основним параметром експлуатаційної готовності СКРП є коефіцієнт готовності, який у ймовірнісному відношенні визначається як

$$
K_{2}=\frac{T_{c p}}{T_{c p}+T_{B}}
$$

$T_{B}=\left(m_{\text {окк }}+m_{\text {паз }}+m_{\phi}+m_{m c}\right) T_{\text {вв }} K_{\text {гк }}=\frac{N_{\phi m n}}{N_{C K P \Pi}} \sum_{i=1}^{m_{\text {окк }}+m_{\text {nas }}+m_{\phi}+m_{m c}} t_{B B_{-} i}$,

$t_{\text {вв_ } i}$ - тривалість верифікації та відновлення одного функціонального модуля СКРП з умовним номером $i$.

3 результатів досліджень ефективності ММПС за критерієм збільшення тестового покриття випробувань випливає, що наведені значення $Y_{2}$ та $Y_{3}$ визначають відповідно обсяги внутрішніх і зовнішніх зв'язків ОКК (складність і масштабність технологічного об'єкта СКРП), звідки загальна масштабність СКРП дорівнюватиме їх добутку: $N_{C К Р \Pi ~}=Y_{2} \times Y_{3}$.

3 урахуванням ізоморфізму між компонентами тестового покриття, встановленого в праці [11], i прийнятих вище обмежень щодо моделі оцінювання тестового покриття випливає рівнозначність масштабності СКРП та загальної кількості ऑiі ОКК, де $T_{c p}$ i $T_{B}-$ відповідно середнє напрацювання до відмови та середній час відновлення СКРП.

Додатково експлуатаційну готовність характеризує інтенсивність відновлення $\mu=1 / T_{B}$ як величина, обернена середньому часу відновлення.

Результуюча середня тривалість відновлення $T_{B}$ СКРП з урахуванням формул (1), (4) і праць $[3,4]$ визначатиметься як добуток сумарної тривалості

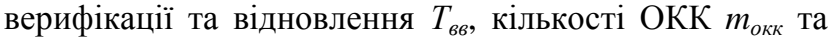
коефіцієнта глибини контролю $K_{\text {гк }}$, що визначається як відношення обсягу тестового покриття до загальної масштабності технологічного об'єкта:

ПАЗ, функцій і технологічних ситуацій $m_{\text {окк }}+m_{\text {nаз }}+m_{\phi}$ $+m_{m c}=N_{\text {СКРП }}$, звідки відбувається скорочення виразів у формулі (19):

$T_{B}=Y_{2} Y_{3} T_{B 8} \frac{N_{\phi m n}}{Y_{2} Y_{3}}=T_{B 8} N_{\phi m n}$.

Шляхом поєднання формул (17) - (20) формуються такі вирази для оцінки середнього часу та інтенсивності відновлення СКРП при здійсненні контролю їхніх функціональних параметрів із використанням ММПС і МПС:

$$
\begin{aligned}
& T_{B}^{\text {миnс }}=T_{6 в}\left(\left(Y_{2}-Y_{3}\right)^{2}+Y_{2}\left(Y_{2}-2 Y_{3}\right)\right), \mu_{B}^{\text {миnс }}=\frac{1}{T_{68}\left(\left(Y_{2}-Y_{3}\right)^{2}+Y_{2}\left(Y_{2}-2 Y_{3}\right)\right)} \text {, } \\
& T_{B}^{\text {мипс }}=T_{\text {вв }}\left(Y_{2}-Y_{3}\right)^{2}, \mu_{B}^{\text {мnc }}=\frac{1}{T_{B в}\left(Y_{2}-Y_{3}\right)^{2}},
\end{aligned}
$$

а відповідні коефіцієнти готовності матимуть такі значення:

$$
\begin{aligned}
& K_{2}^{\text {unnc }}=\frac{T_{c p}}{T_{c p}+T_{B b}\left(\left(Y_{2}-Y_{3}\right)^{2}+Y_{2}\left(Y_{2}-2 Y_{3}\right)\right)}, \\
& K_{2}^{\text {snc }}=\frac{T_{c p}}{T_{c p}+T_{B b}\left(Y_{2}-Y_{3}\right)^{2}} .
\end{aligned}
$$

Відповідно до формули (21) виграш в інтенсивності відновлення СКРП при застосуванні розробленого методу визначається виразом 
$\delta \mu_{C K P \Pi}=\frac{\mu_{C K P \Pi}^{\text {мunc }}}{\mu_{C K P \Pi}^{\text {snc }}}=\frac{T_{в 8}\left(Y_{2}-Y_{3}\right)^{2}}{T_{в 8}\left(\left(Y_{2}-Y_{3}\right)^{2}+Y_{2}\left(Y_{2}-2 Y_{3}\right)\right)}=\frac{\left(Y_{2}-Y_{3}\right)^{2}}{\left(Y_{2}-Y_{3}\right)^{2}+Y_{2}\left(Y_{2}-2 Y_{3}\right)}$,

що демонструється поверхнями на рис. 6.

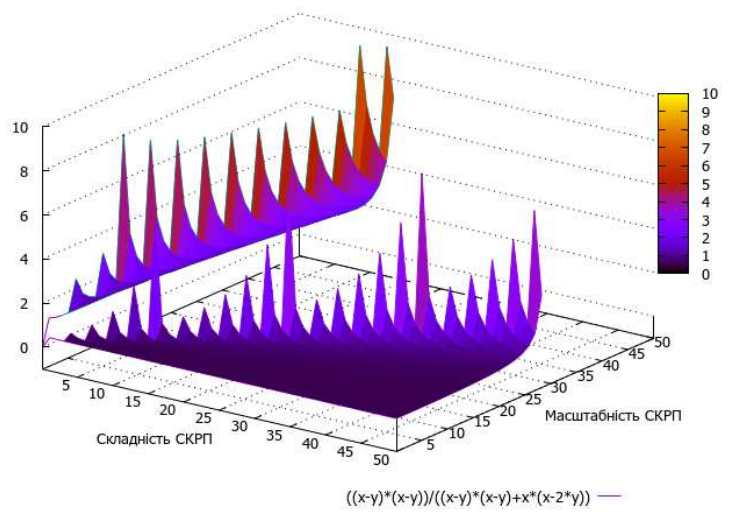

Рис. 6. Поверхневий графік виграшу в інтенсивності відновлення СКРП

3 наведених поверхонь випливає, що за виключенням точок нескінченного розриву найбільше збільшення інтенсивності відновлення відбувається при максимальній відповідності складності та масштабності СКРП, при цьому спостерігається позитивна монотонність для цього параметра всіх значень кількості внутрішніх і зовнішніх зв'язків. Точки нескінченного розриву визначають значення, при яких втрачає сенс використання розроблених методів і моделей випробувань, пояснення характеру їхніх закономірностей вимагає окремого дослідження

Відповідно до формули (21) і (22) підвищення експлуатаційної готовності СКРП з точку зору збільшення коефіцієнта $\delta K_{2}$ готовності визначається як

$$
\begin{aligned}
& \delta K_{2}=\frac{T_{c p}\left(T_{c p}+T_{B 8}\left(Y_{2}-Y_{3}\right)^{2}\right)}{T_{c p}\left(T_{c p}+T_{b 8}\left(\left(Y_{2}-Y_{3}\right)^{2}+Y_{2}\left(Y_{2}-2 Y_{3}\right)\right)\right)}= \\
& =\frac{T_{c p}+T_{B 8}\left(Y_{2}-Y_{3}\right)^{2}}{T_{c p}+T_{68}\left(\left(Y_{2}-Y_{3}\right)^{2}+Y_{2}\left(Y_{2}-2 Y_{3}\right)\right)} .
\end{aligned}
$$

Як випливає 3 отриманого виразу, інтенсивність збільшення коефіцієнта готовності СКРП залежить від середнього напрацювання до відмови та середньої тривалості відновлення і верифікації одного функціонального модуля. При вихідних значеннях цих параметрів на рівні одного року та 12 хвилин закономірність, визначена формулою (24), інтерпретована у відсотки, демонструється 3Dповерхнею, зображеною на рис. 7.

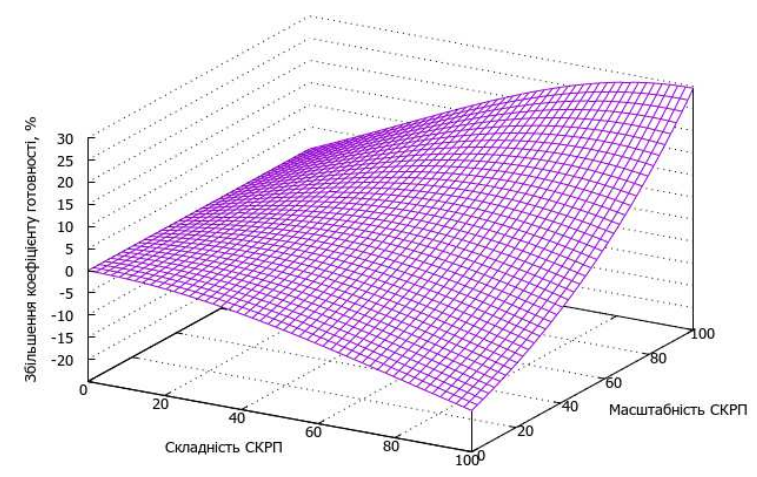

$\left.\left(\left(8760+0.2^{*}(x-y) *(x-y)\right)\right) /\left(8760+0.2^{*}\left((x-y) *(x-y)+x^{*}\left(x-2^{*} y\right)\right)\right)-1\right)^{*} 100$

Рис. 7. Поверхневий графік виграшу в коефіцієнті готовності СКРП

3 отриманої поверхні випливає певний діапазон співвідношень між обсягом внутрішніх і зовнішніх зв'язків ОКК СКРП, при яких розроблені методи та моделі функціональних випробувань мають ефективність щодо підвищення коефіцієнта готовності. Шляхом встановлення обмежень, при яких спостерігається збільшення, а не зменшення коефіцієнта готовності, зазначена область (діапазон) визначається поверхневим графіком на рис. 8 .

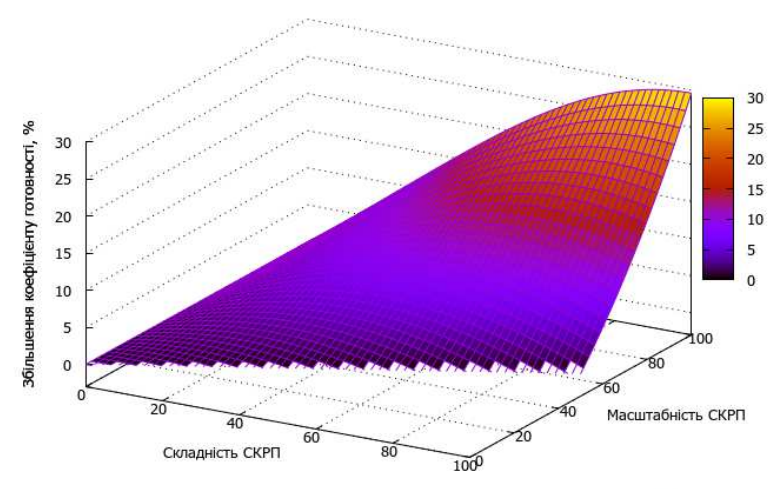

$\left(\left(8760+0.2^{*}(x-y) *(x-y)\right) /\left(8760+0.2^{*}\left((x-y) *(x-y)+x^{*}\left(x-2^{*} y\right)\right)\right)-1\right)^{*} 100-$

Рис. 8. Область збільшення коефіцієнта готовності СКРП

Як випливає 3 отриманої поверхні, підвищення коефіцієнта готовності СКРП відбувається тільки за умови, коли складність технологічних об'єктів СКРП не перевищує їхньої масштабності. Зазначена умова $€$ умовою припустимості використання розроблених методів i моделей контролю функціональних параметрів, при яких досягається підвищення експлуатаційної готовності СКРП. 
Висновки 3 дослідження і перспективи, подальший розвиток у даному напрямку

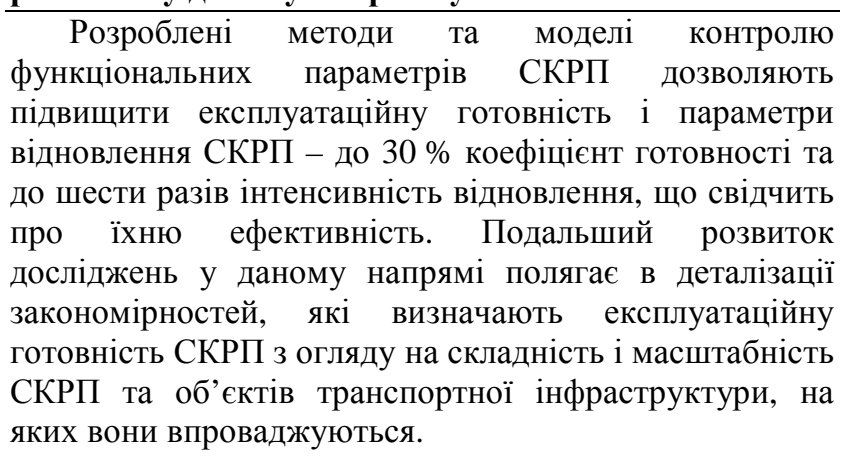

\section{Список використаних джерел}

1. Про схвалення Національної транспортної стратегії України на період до 2030 року: Розпорядження Кабінету міністрів України від 30 травня 2018 р. № 430-p / Кабінет міністрів України. Офіційний вісник України. 2018. № 52. С. 533. Ст. 1848. Код акта 90720/2018.

2. Бочков К. А., Харлап С. Н. Методы обеспечения безопасности в микропроцессорных системах железнодорожной автоматики и телемеханики: учеб. пособие для студ. трансп. спец. высш. учеб. заведений. Гомель: БелГУТ, 2001. 84 с.

3. Каракаев А. Б., Луканин А. В. Исследование основных зависимостей между показателям между показателями надежности и показателями глубины контроля судового электрооборудования. Вестник Государственного университета морского и речного флота имени адмирала С. О. Макарова. 2016. Вып. 3 (37). С. 180-192.

4. Иванов Д. Е., Громова Т. В., Швецова-Шиловская T. Н. Автоматизированный анализ контролепригодности систем контроля технологического оборудования на опасных производственных объектах. Вестник МГТУ им. Н. Э. Баумана. Сер. «Приборостроение». Москва, 2016. № 3. С. 114-128. DOI: 10.18698/0236-3933-2016-3-114-128.

5. Markevicius V., Navikas D., Idzkowski A., Andriukaitis D., Valinevicius A., Zilys M. Practical Methods for Vehicle Speed Estimation Using a Microprocessor-Embedded System with AMR Sensors. Sensors (Basel). 2018. Vol. 18(7): 2225. P. 1-12. DOI: $10.3390 / \mathrm{s} 18072225$.

6. S,ENER I., KAYMAKC O. T., USTO GLU 'I, CANSEVER G. Specification and formal verification of safety properties in a point automation System. Turkish Journal of Electrical Engineering \& Computer Sciences. 2016. Vol. 24. P. 1384-1396. DOI:10.3906/elk-1311-27.

7. Fantechi A., LecomteT., Romanovsky A. Reliability, Safety, and Security of Railway Systems. Modelling, Analysis, Verification, and Certification: second
International conference, RSSRail, 2017 Pistoia, Italy, November 14-16, 2017 Proceedings. 2017. Pistoia. Italy. P. 217. DOI: 10.1007/978-3-319-68499-4.

8. Kans M., Galar D., Thaduri A. Maintenance 4.0 in Railway Transportation Industry. A data fusion approach of multiple maintenance data sources for real-world reliability modeling. 2016. P. 317-331. DOI: 10.1007/978-3-319-27064-7_30.

9. Hwang J.-G., Baek J.-H., Jo H.-J., Lee K.-M. Blackbox testing tool of railwaysignalling system software with a focus on user convenience. WIT Transactions on The Built Environment. Korea. 2014. Vol 135. P. 99-108. DOI:10.2495/CR140081.

10. Chen X., Wang D., Huang H., Wang Z. Verification and validation in railway signalling engineering - an application of enterprise systems techniques. Enterprise Information Systems. 2014. Vol. 8:4. P. 490-511. DOI: $10.1080 / 17517575.2013 .835071$.

11. Listrovoy S., Panchenko S., Listrova E. Mathematical models in computer control systems railways and parallel computing: monograph. Kharkiv, 2017. 300 p.

12. Boinik A., Prohonnyi O., Kameniev O., Kuzmenko D., Shcheblykina O. Development and investigation of methods of graphic-functional modeling of distributed systems. Eastern-European Journal of Enterprise Technologies. 2018. Vol. 94. № 4/4. P. 59-69. DOI: 10.15587/17294061.2018.140636 (видання індексується в базі Scopus).

13. Кустов В. Ф., Каменев А. Ю. Экспериментальностатические модели распределённых технологических объектов. Металлургическая $u$ горнорудная промышленность. 2013. № 2 . C. $97-101$

14. Каменєв О. Ю. Удосконалення методів контролю параметрів системи мікропроцесорної централізації. Інформаційно-керуючі системи на залізничному транспорті: науково-технічний журнал. Харків: УкрДУЗТ, 2013. Вип. 3. С. 75-77.

Щеблыкина Е. В., Каменев А. Ю., Лапко А. А., Сагайдачный В. Г. Повышение показателей готовности и восстановления систем управления движением поездов на основании увеличения глубины контроля.

Аннотация. Бесперебойность процессов перевозок железнодорожным транспортом определяется эксплуатационной надежностью систем управления движением поездов. Одними из важнейших их параметров, определяющих работоспособность и исправность систем управления, является эксплуатационная пригодность к регулированию движения поездов и производству маневровой работы, а также способность к восстановлению после отказов. Они определяются коэффициентами готовности и интенсивностью восстановления соответственно. С целью повышения данных показателей в опубликованном 
исследовании, опираясь на последние научные достижения, разработана модель оценки глубины контроля функциональных параметров систем управления движением поездов, который осуществляется путем функциональных испытаний. На основании научных данных, которые определяют взаимосвязь между коэффициентом готовности, интенсивностью восстановления технических средств и глубиной их контроля, установлены закономерности, определяющие увеличение эксплуатационной готовности и показателей восстановления систем управления движения поездов при изменении масштабности и сложности технологических объектов. Разработан метод, который позволяет на основе увеличения глубины контроля добиться повышения эксплуатационной готовности и параметра восстановления систем управления движением поездов соответственно до $30 \%$ и до шести раз. С учетом корреляции между отказами устройств управления движением поездов и их задержками указанные результаты позволяют уменьшить непродуктивный простой поездов до $15 \%$.

Ключевые слова: системы управления движением поездов, надежность, готовность, восстановление, глубина контроля, тестовое покрытие, функциональные испытания.

Shcheblykina O., Kameniev O., Lapko A. Sagajdachnyj V. Improving readiness and recovery indicators of train traffic control systems based on increasing the depth of control.

Abstract. Continuity of the processes of transportation by rail is determined by the operational reliability of train control systems. One of their most important parameters, which determine the operability and serviceability of control systems, is serviceability for regulating train traffic and performing shunting operations, as well as the ability to recover from failures. They are determined by availability factors and recovery rates, respectively. In order to increase these indicators in the published study, based on the latest scientific achievements, a model has been developed for assessing the depth of control of the functional parameters of train traffic control systems, which is carried out through functional tests. On the basis of scientific data that determine the relationship between the availability factor, the rate of recovery of technical means and the depth of their control, regularities have been established that determine the increase in the operational readiness and recovery rates of train traffic control systems when the scale and complexity of technological facilities change. A method has been developed that allows, on the basis of increasing the depth of control, to achieve an increase in operational readiness and the parameter of restoration of train traffic control systems, respectively, up to $30 \%$ and up to six times. Taking into account the correlation between the failures of train control devices and their delays, the indicated results make it possible to reduce the unproductive idle train up to $15 \%$.
Key words: train traffic control systems, reliability, availability, restoration, control depth, test coverage, functional tests.

Надійшла 04.09.2020 p.

Щебликіна Олена Вікторівна, аспірант кафедри автоматики та комп'ютерного телекерування рухом поӥздів, Украӥнський державний університет залізничного транспорту, Харків, Украӥна. E-mail: sov@kart.edu.ua. ORCID ID: 0000-0002-8304-2921

Каменєв Олександр Юрійович, кандидат технічних наук, доиент кафедри автоматики та комп'ютерного телекерування рухом поӥздів, Український держсавний університет залізничного транспорту, Харків, Україна. E-mail: alexstein@kart.edu.ua. ORCID ID: 0000-0001-53725628

Лапко Антон Олександрович, кандидат технічних наук, дочент кафедри автоматики та комп'ютерного телекерування рухом поӥздів, Український державний університет залізничного транспорту, Харків, Україна. Еmail:a.o.lapko@kart.edu.ua. ORCID ID:0000-0003-2881-1238 Сагайдачний Владислав Геннадійович, аспірант кафедри автоматики та комп'ютерного телекерування рухом поӥздів, Украӥнський державний університет залізничного транспорту, Харків, Украӥна. E-mail: v.sahaidachnyi@kart.edu.ua. ORCID ID: 0000-0003-2511$\underline{9852}$

Shcheblykina Olena Viktorivna, graduate of department of automatic and computer remote control of train traffic, Ukrainian State University of Railway Transport, Kharkiv, Ukraine.E-mail:sov@kart.edu.ua. ORCID ID: 0000-00028304-2921

Kameniev Oleksandr Jurijovych, Ph.D.(Eng.), associate professor of department of automatic and computer remote control of train traffic, Ukrainian State University of Railway Transport, Kharkiv, Ukraine. E-mail: alexstein@kart.edu.ua. ORCID ID: 0000-0001-5372-5628

Lapko Anton Oleksandrovych, Ph.D.(Eng.), associate professor of department of automatic and computer remote control of train traffic, Ukrainian State University of Railway Transport, Kharkiv, Ukraine. E-mail: a.o.lapko@kart.edu.ua. ORCID ID: 0000-0003-2881-1238

Sahaidachnyi Vladyslav Hennadiiovych, postgraduate Department of automatic and computer remove control of train traffic, Ukrainian State University of Railway Transport, Kharkiv, Ukraine. E-mail: v.sahaidachnyi@kart.edu.ua ORCID ID: 0000-0003-2511-9852 